\title{
DOSSIER FOTOGRÁFICO
}

Imágenes de Armindo Cardoso

Las imágenes son gentileza de la Biblioteca Nacional Digital. 



\section{ARMINDO CARDOSO}

Fotógrafo portugués nacido en la ciudad de Porto en 1943. Llegó a Chile en 1969 y trabajó como asistente del fotógrafo polaco Bob Borowicz en la Universidad de Concepción. En 1972 integra el equipo fundador del semanario Chile Hoy. Debido a su trabajo y cercanía con el gobierno de la Unidad Popular del Presidente Salvador Allende, fotografía diversos hitos de la época como la implementación de la Reforma Agraria, la visita de Fidel Castro a Chile y la expropiación de las fábricas Sumar y Yarur. También colaboró con la película "La Batalla de Chile" y retrató a grandes personajes de la época, como el poeta Pablo Neruda. 


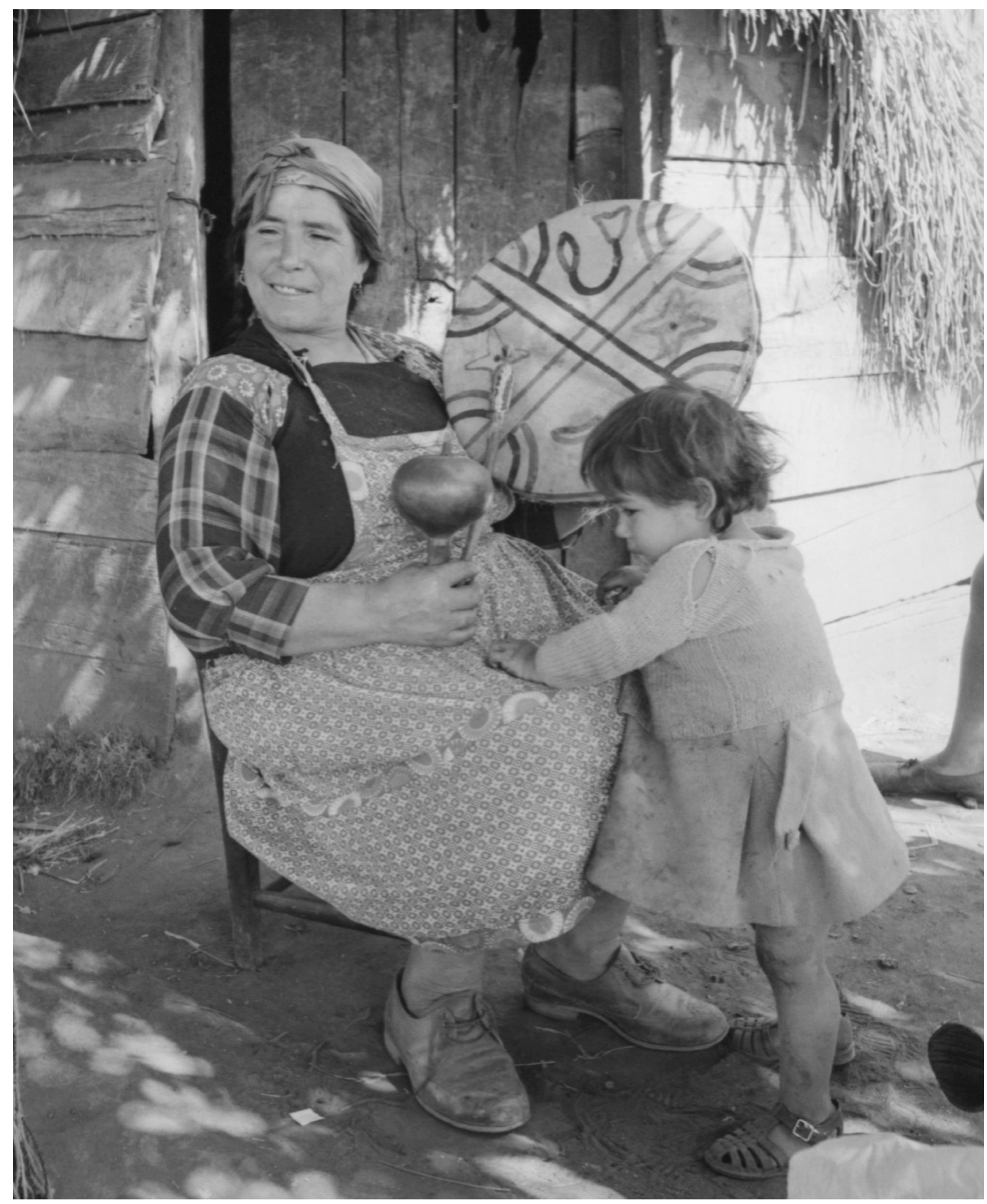

El día a día de una familia mapuche: una mujer con sus [hijos] sentada afuera de su ruca bebiendo y tocando el kultrú, año 1971, Nueva Imperial. 


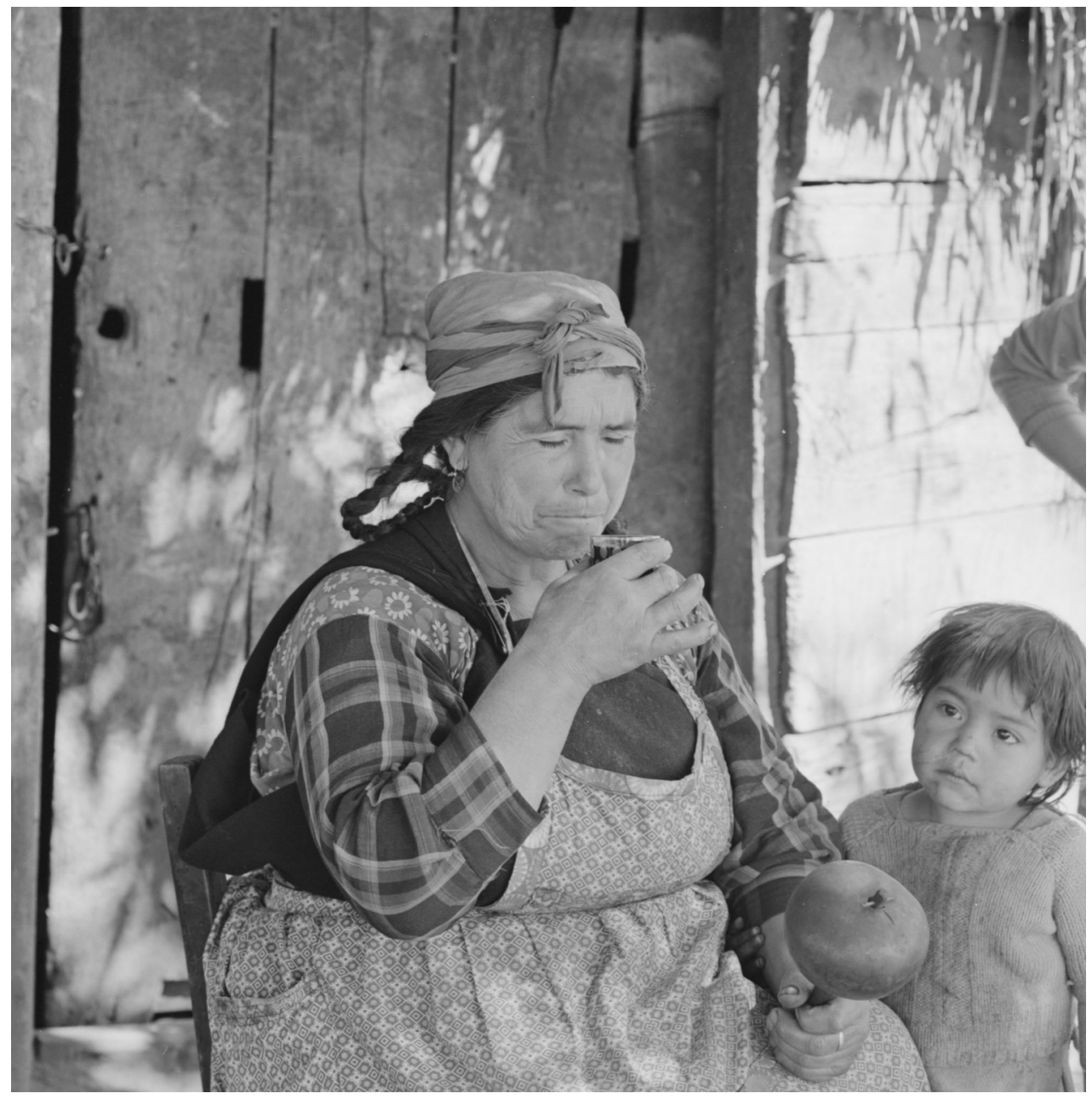

El día a día de una familia mapuche: una mujer con sus [hijos] sentada afuera de su ruca bebiendo y tocando el kultrú, año 1971, Nueva Imperial. 


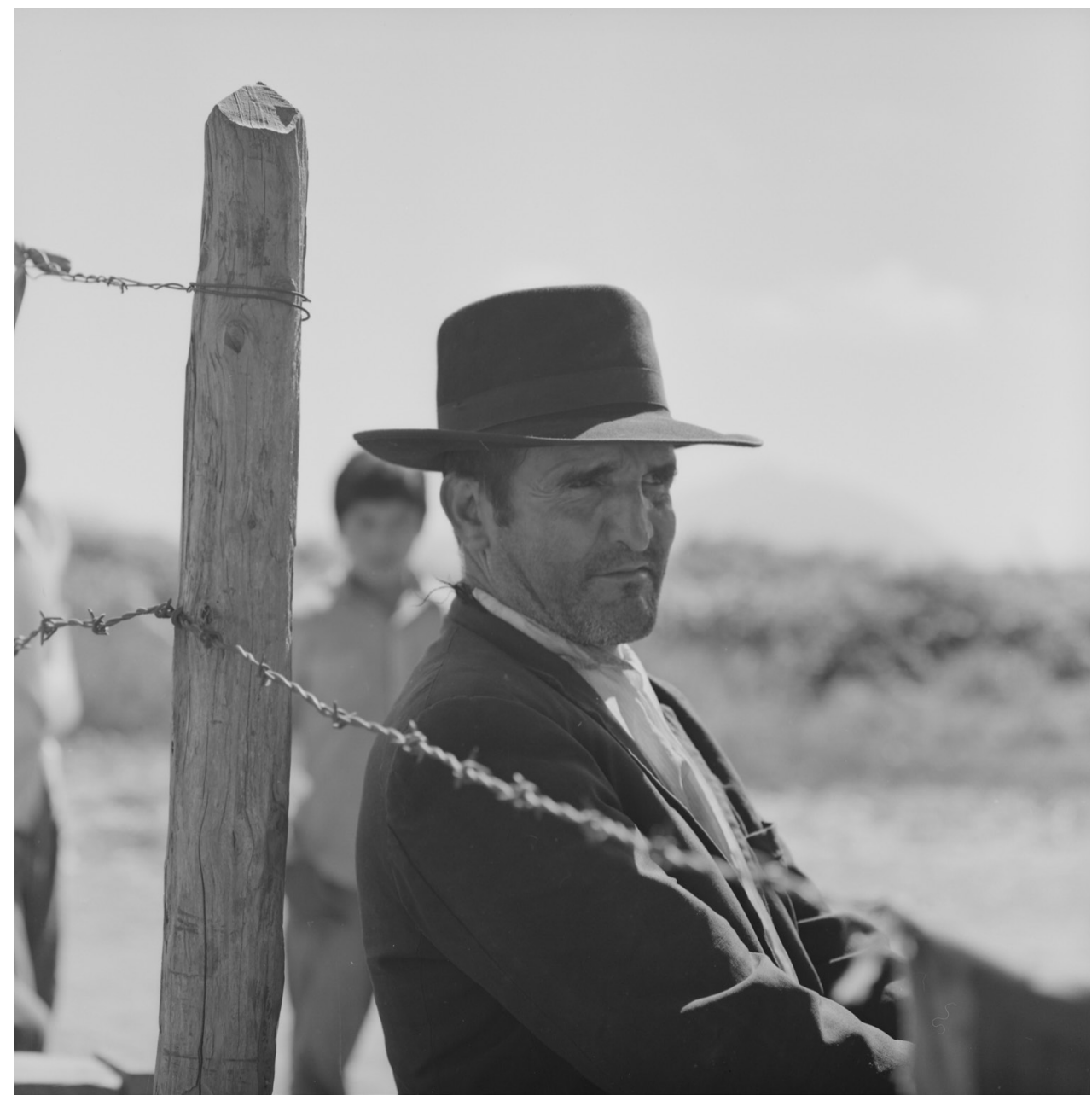

Un campesino vestido de huaso [arriando el ganado de bueyes por los caminos de tierra (levantando polvoreda) en pleno campo de la ciudad de Talca]. Esto fue durante el Censo de afuerinos, realizado en Talca en el marco de la RA, año 1972. 


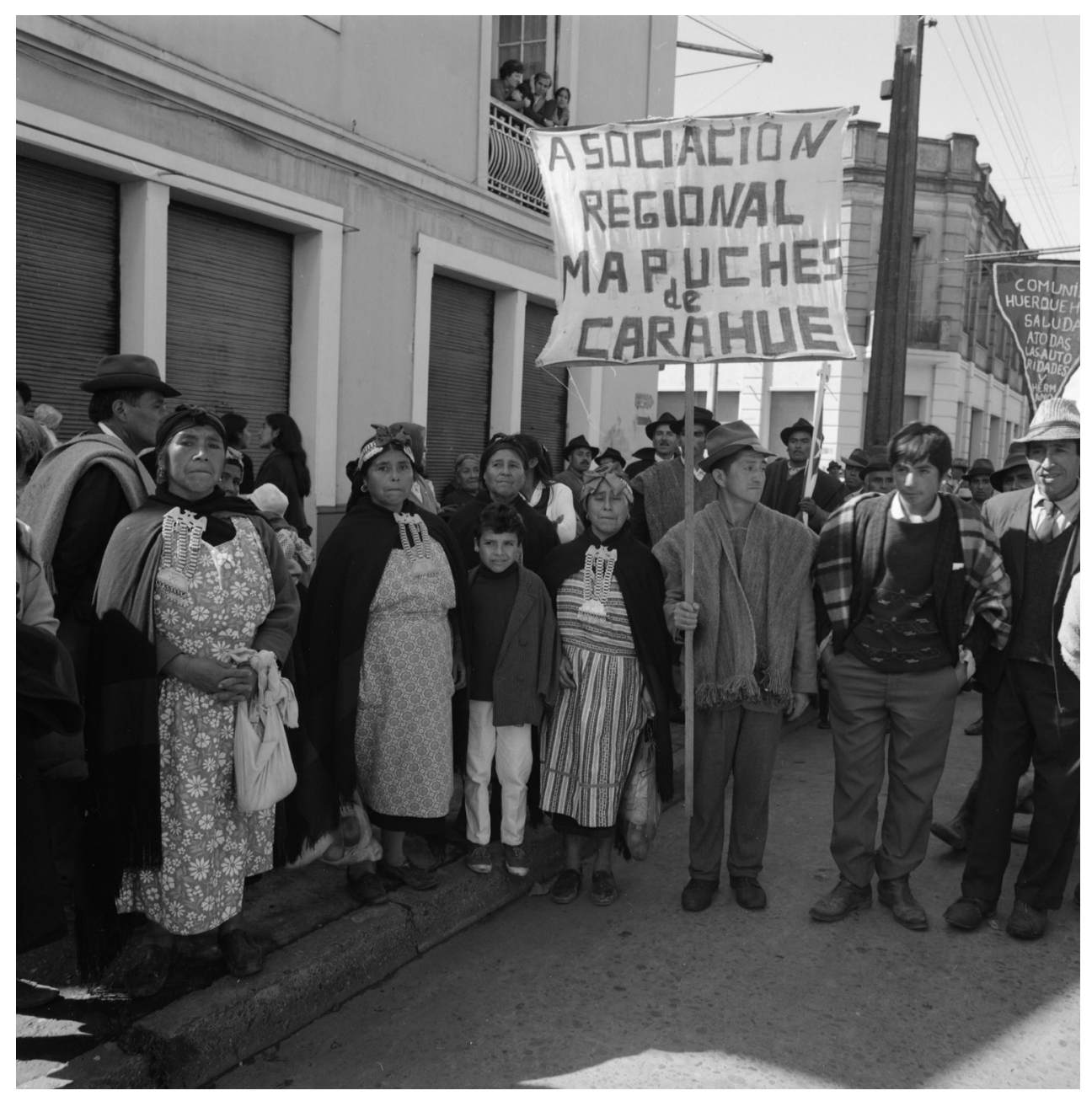

Salvador Allende llega a Temuco en el mes de marzo del año 1971, en el marco de la Reforma Agraria para profundizarla y entregar a la población mapuche las herramientas para su inserción en el mundo agrícola. El día 28 se crea el Instituto de Capacitación Mapuche. Gran concentración de habitantes y mapuches de la Región de La Araucanía, portando carteles. 


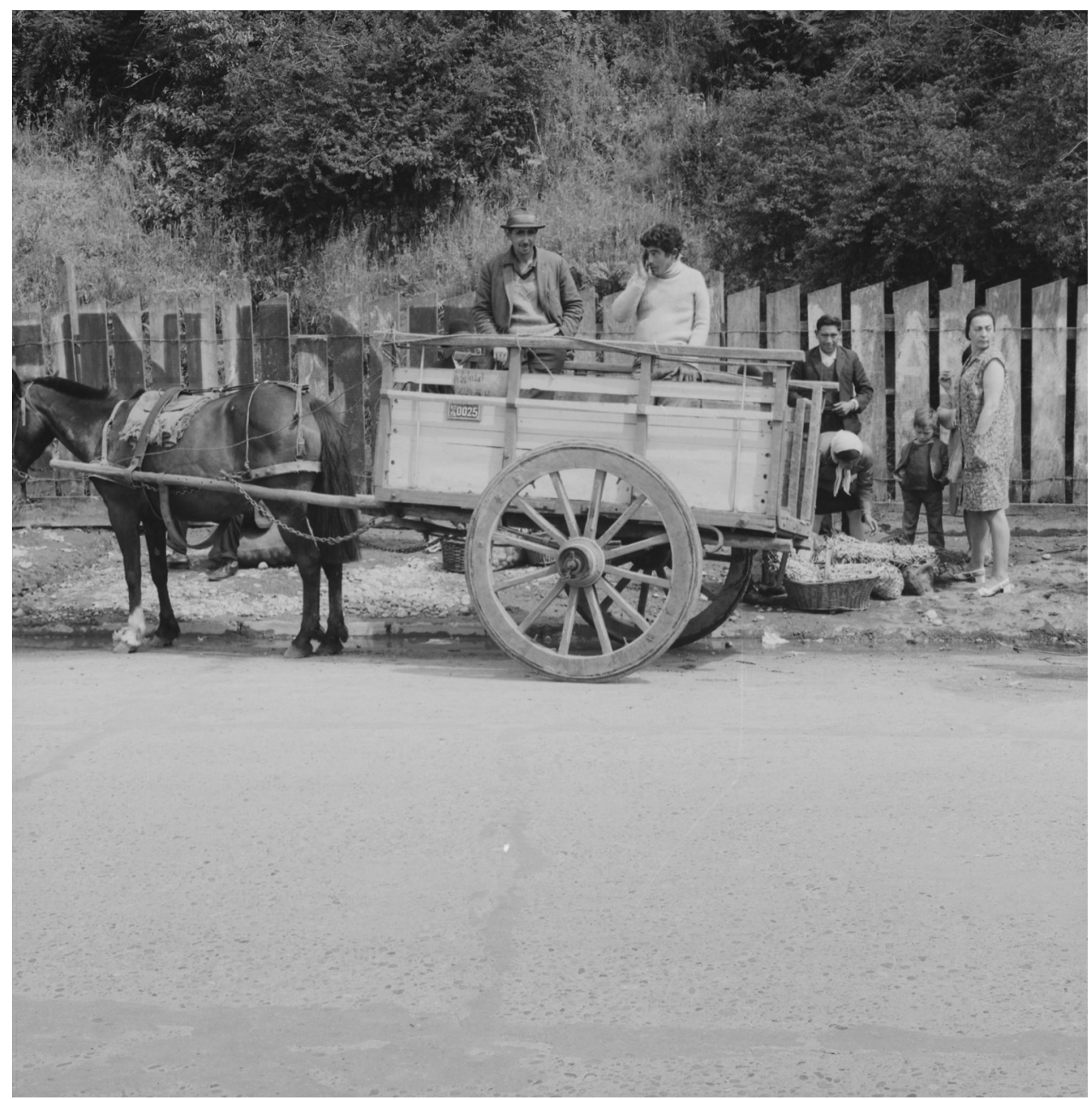

Dos hombres arriba de una carretela patente A0025 venden sus productos ubicados en canastas depositadas en el suelo; una mujer dueña de casa con una lista en la mano y una bolsa para echar las verduras y, otra señora agachada mirando la calidad de los productos, en el marco de la Reforma Agraria, Angelmó, año 1971. 




Niño sentado afuera de su ruca, rodeado de animales, Temuco, 1972. 


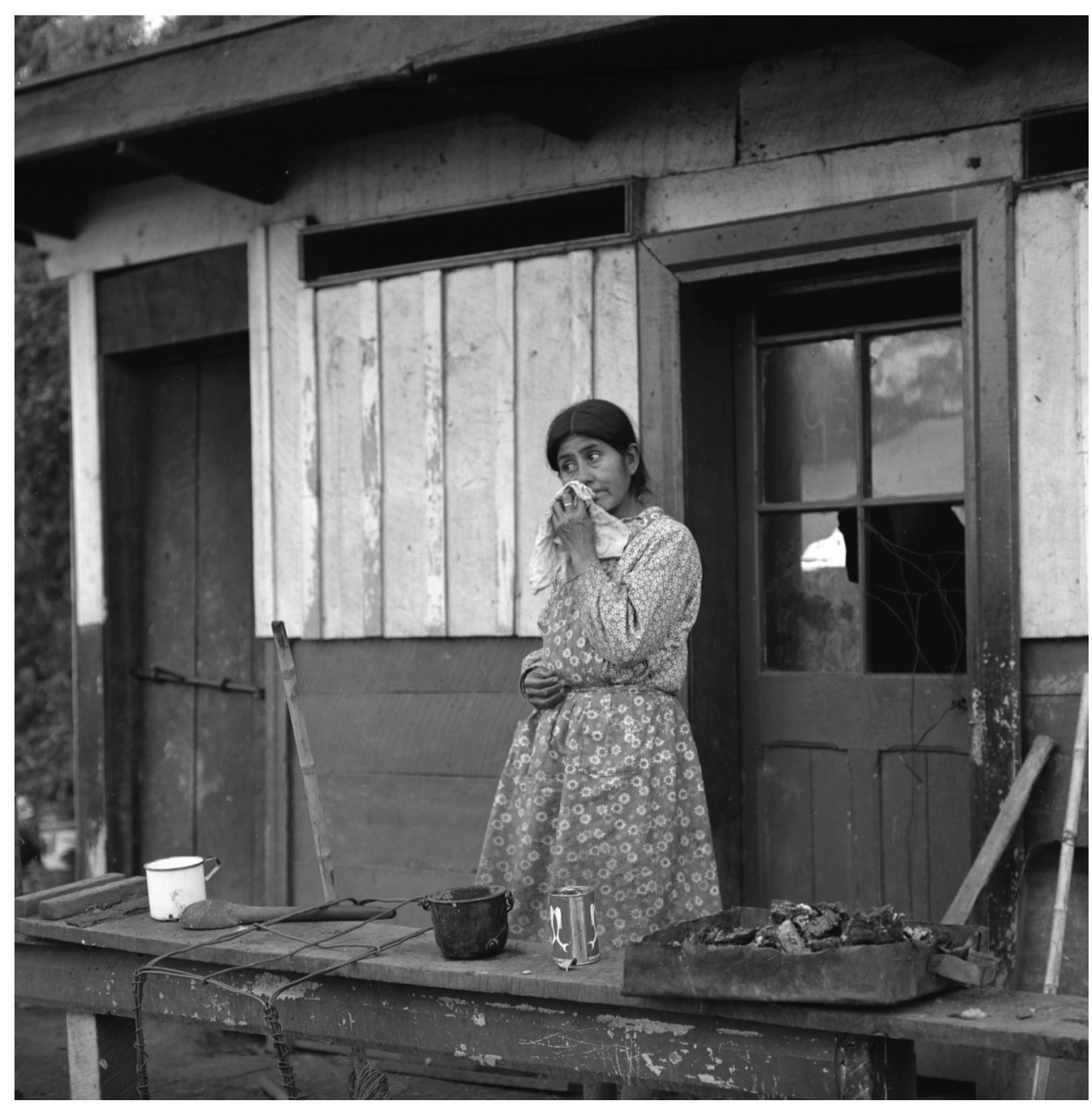

Mujer campesina, Talca, 1971. 


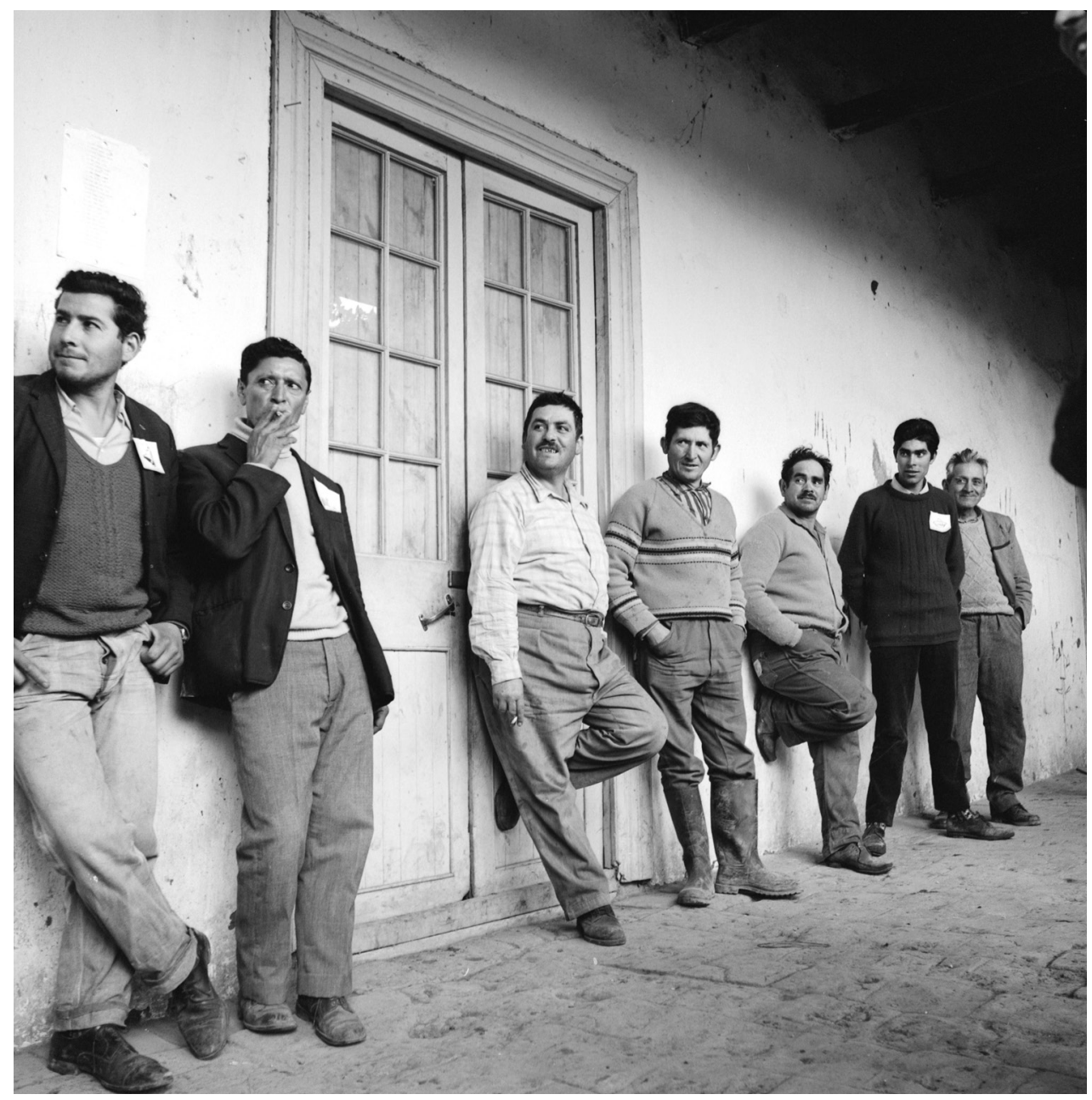

Campesinos agricultores de la zona de Talca reunidos, en el marco de la Reforma Agraria. Varios de ellos tienen una credencial de la que no se distingue su información. Talca, 1971. 


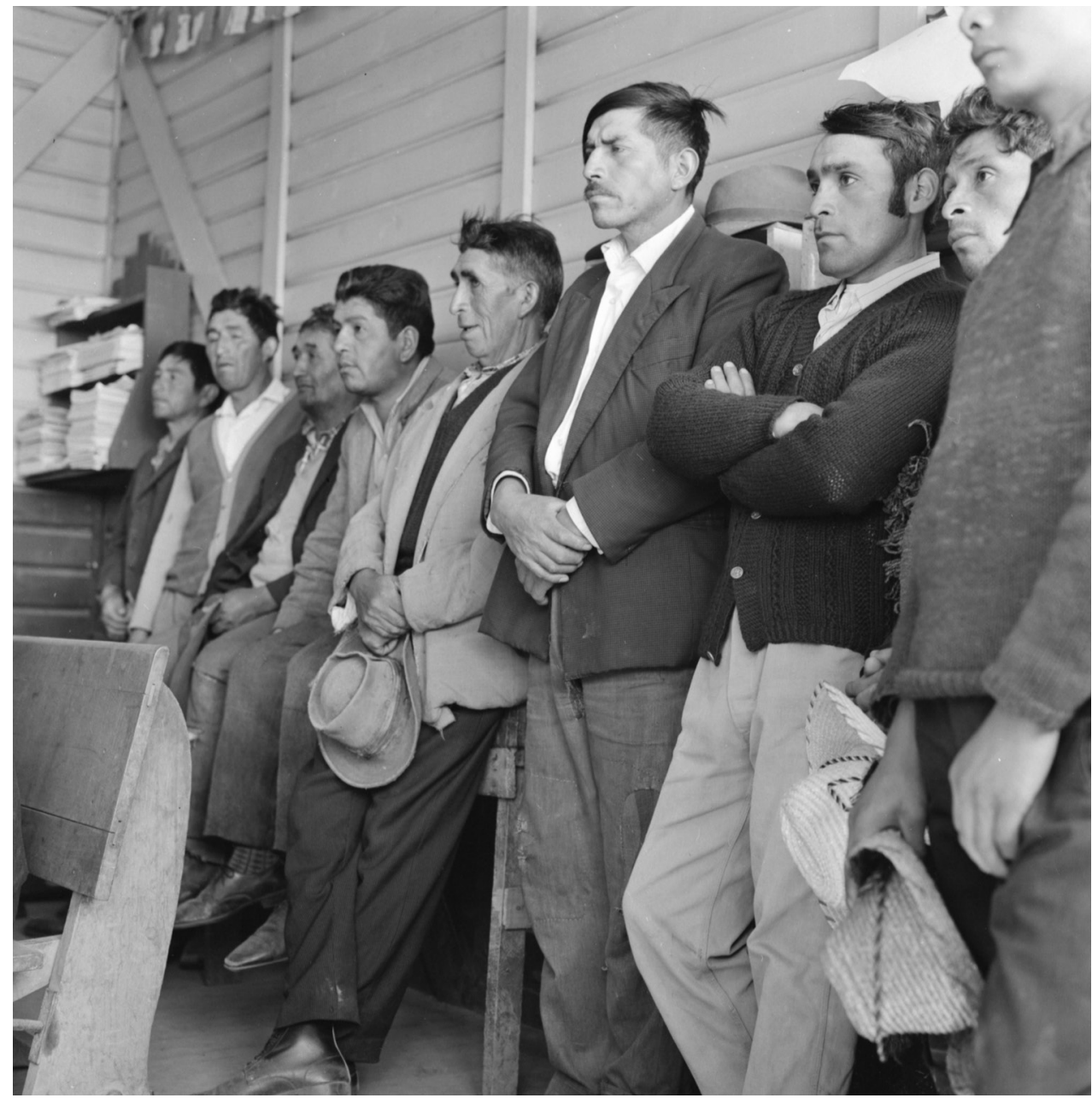

Mapuches reunidos en sus asambleas organizándose y trabajando para recuperar sus tierras y llevar adelante la Reforma Agraria. Muchos de ellos están detenidos desaparecidos, otros fueron fusilados. En la organización de los mapuches respecto de toma de tierras e instalación de campamentos, el MIR y el MCR jugaron un rol muy importante. 


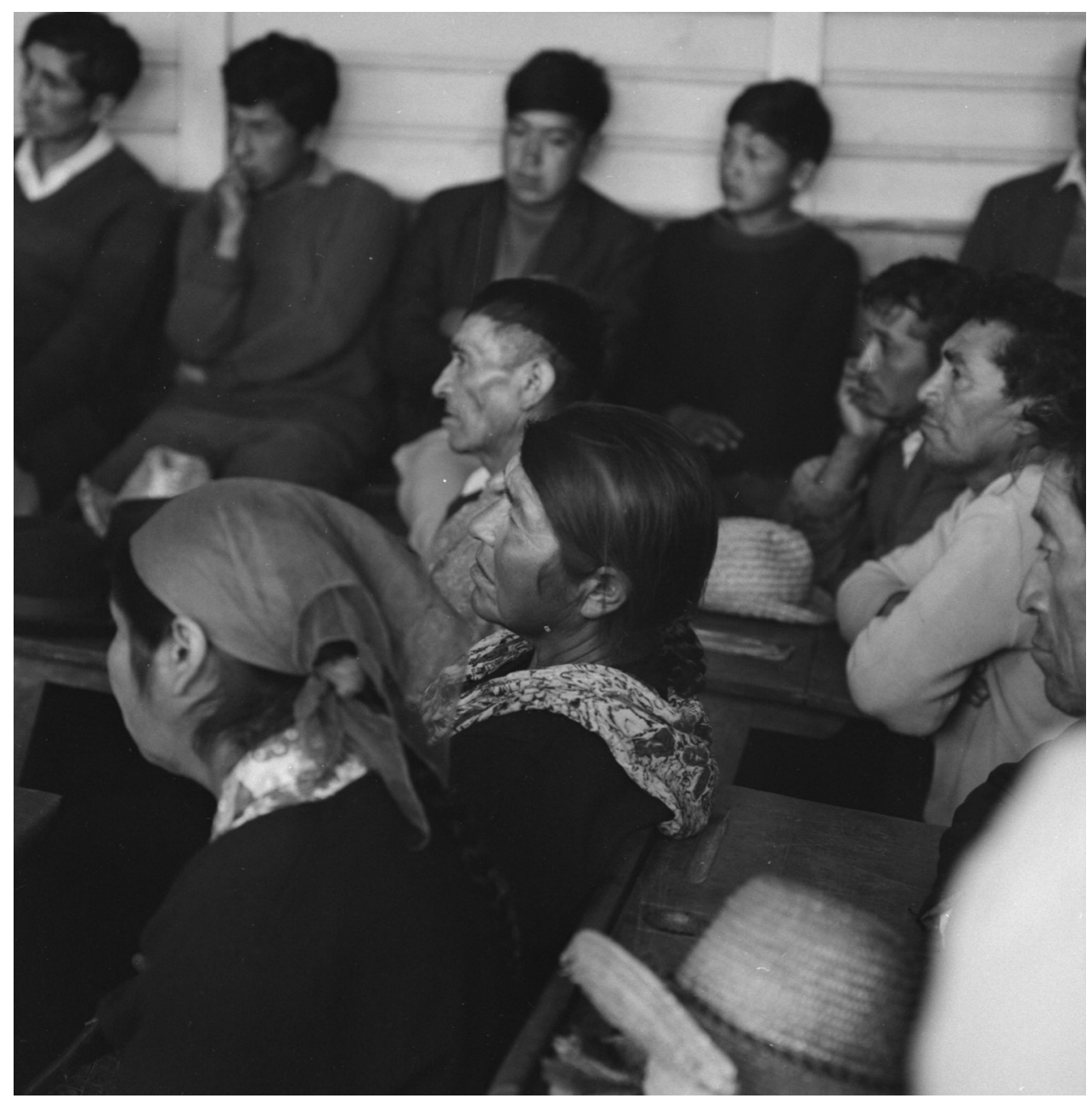

Mapuches reunidos en sus asambleas organizándose y trabajando para recuperar sus tierras y llevar adelante la Reforma Agraria. Muchos de ellos están detenidos desaparecidos, otros fueron fusilados. En la organización de los mapuches respecto de toma de tierras e instalación de campamentos, el MIR y el MCR jugaron un rol muy importante. 


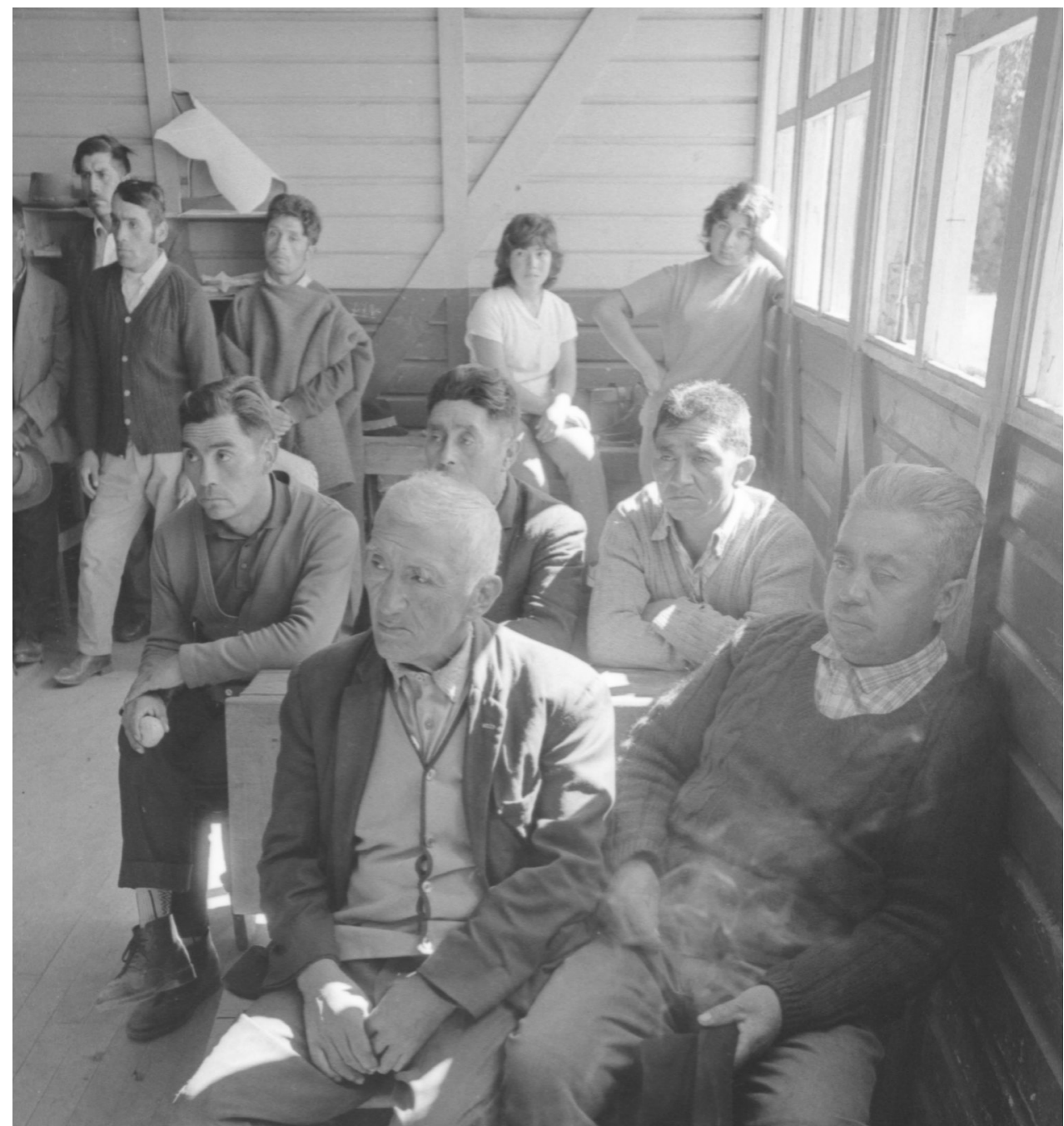

Mapuches reunidos en sus asambleas organizándose y trabajando para recuperar sus tierras y llevar adelante la Reforma Agraria. Muchos de ellos están detenidos desaparecidos, otros fueron fusilados. En la organización de los mapuches respecto de toma de tierras e instalación de campamentos, el MIR y el MCR jugaron un rol muy importante. 


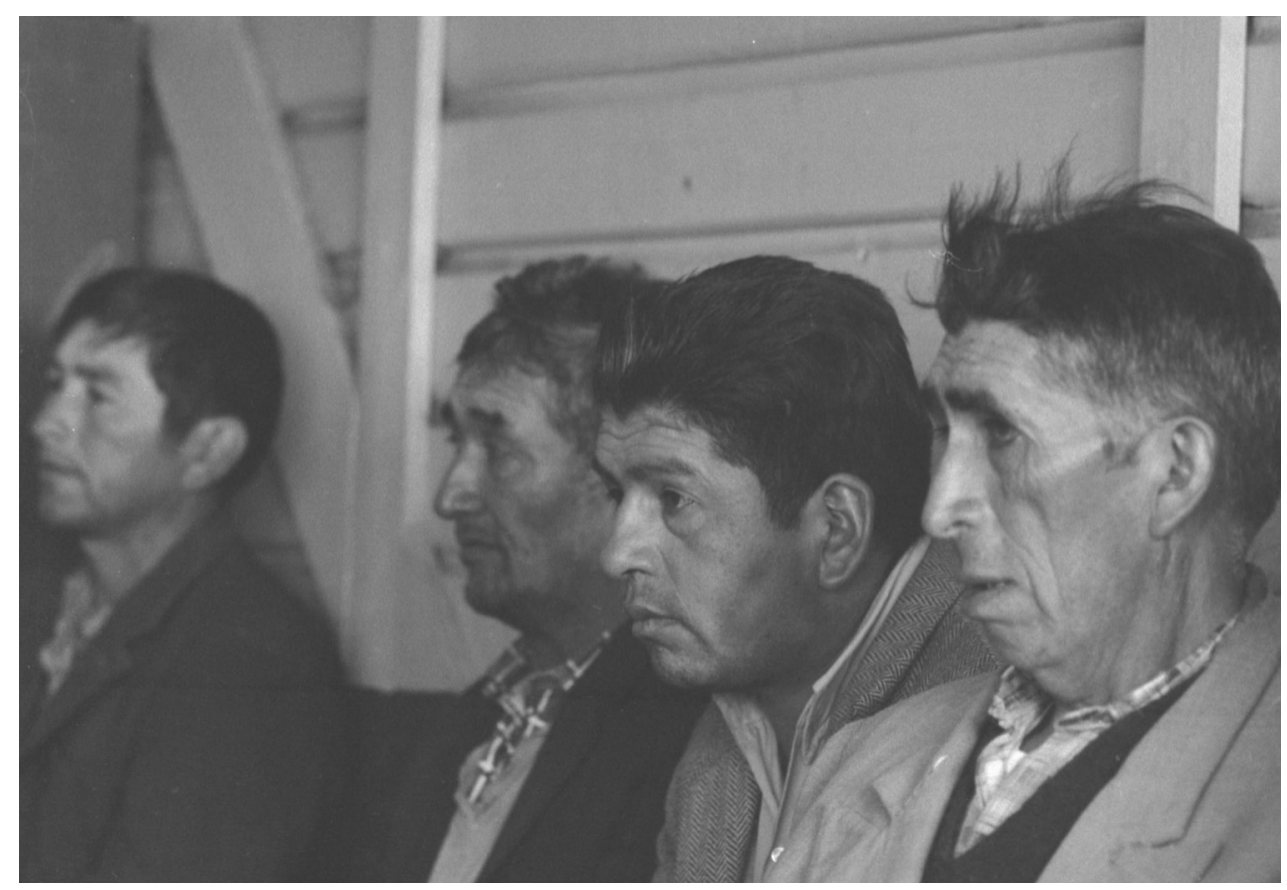

Mapuches reunidos en sus asambleas organizándose y trabajando para recuperar sus tierras y llevar adelante la Reforma Agraria. Muchos de ellos están detenidos desaparecidos, otros fueron fusilados. En la organización de los mapuches respecto de toma de tierras e instalación de campamentos, el MIR y el MCR jugaron un rol muy importante. 


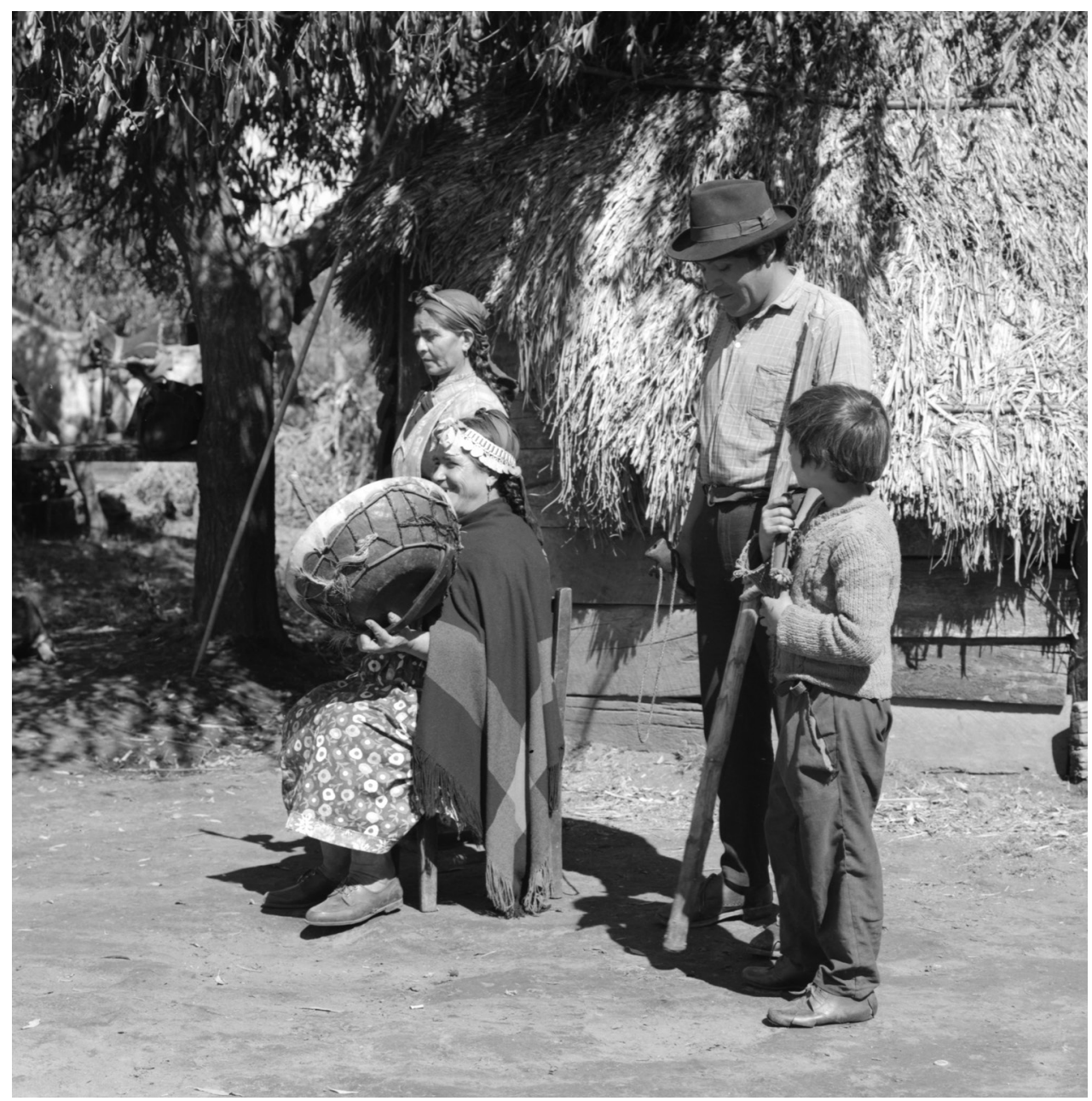

Grupo familiar mapuche compuesto por dos mujeres, tres hombres y un niño, posa alrededor de su ruca. Cada uno de ellos porta algún instrumento o artículo elaborado por ellos. 


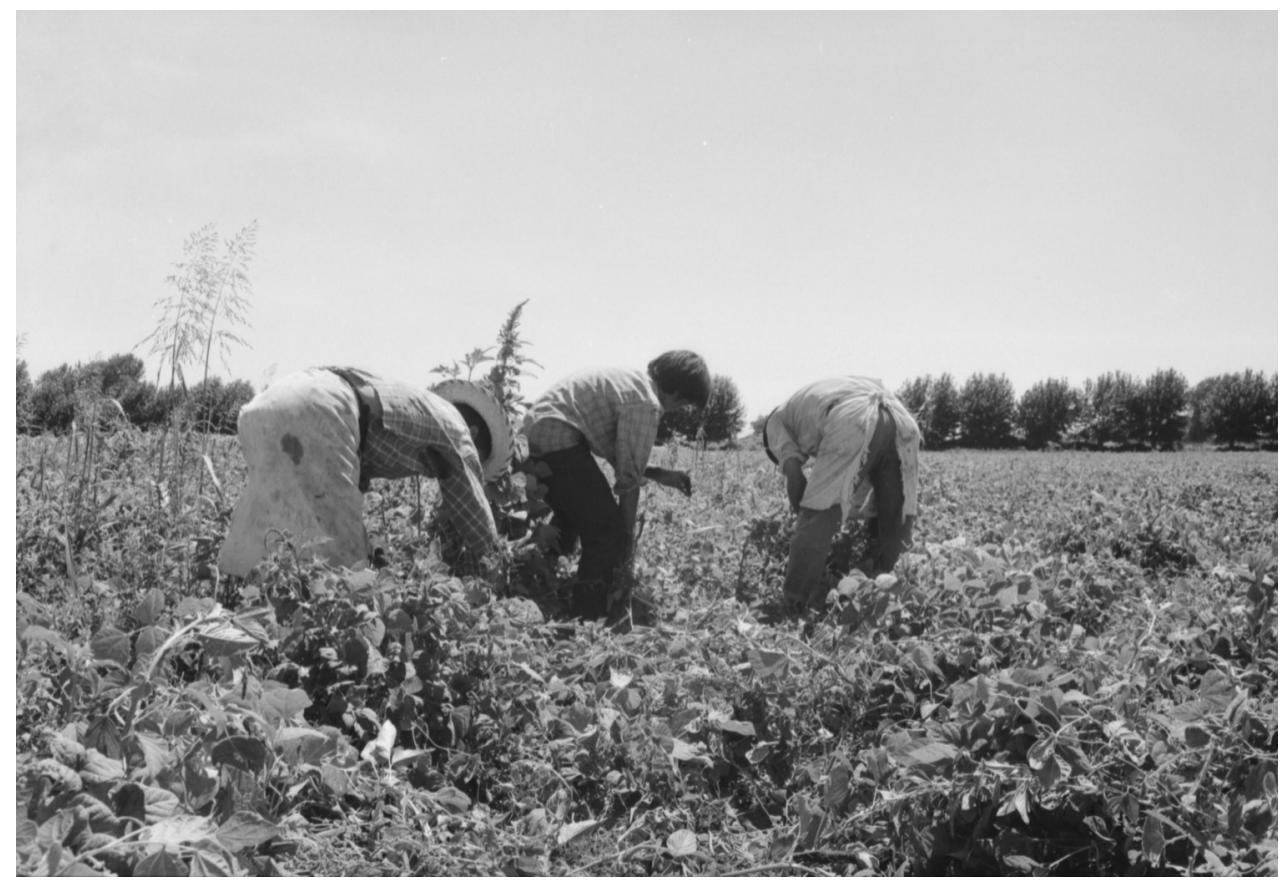

Campesinos agrícolas de Talca cosechando papas. 
